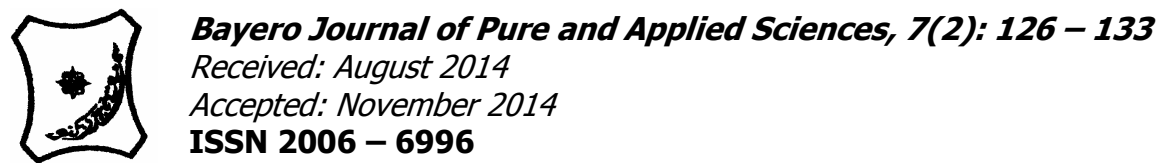

\title{
STUDIES ON THE FOLIAR EPIDERMAL TISSUES OF THREE SPECIES OF Digitaria Haller IN JOS, PLATEAU STATE NIGERIA
}

\author{
Okanume, E. Ogochukwu, ${ }^{1}$ Lawrence, D. A., ${ }^{1}$ Jayeola, A. A. ${ }^{2}$ and Agaba, O. A. ${ }^{1}$ \\ ${ }^{1}$ Department of Plant Science and Technology, University of Jos, Plateau State. \\ ${ }^{2}$ Department of Botany, University of Ibadan, Ibadan \\ Correspondence author: ogochuks2005@yahoo.com
}

\begin{abstract}
Foliar epidermal studies were carried out on Digitaria iburua Stapf, Digitaria exilis Stapf and Digitaria barbinodis Henr. with the aim of determining the patterns of variation in their epidermal characteristics and assessing the value of leaf epidermal characters in the identification of these culturally important species. Micro hairs, silica bodies, short cells, anticlinal wall pattern, epidermal cell shape and stomata index were diagonistic characters. While micro hairs were distributed on the surfaces of Digitaria exilis and Digitaria barbinodi, they were absent in Digitaria iburua. Short cells were present on the surfaces of Digitaria iburua and Digitaria barbinodis but absent on Digitaria exilis. Stomata index was smallest in Digitaria barbinodis distinguishing it from the other two species. The epidermal cell shape varied from rectangular to polygonal while the anticlinal wall pattern varied from straight to wavy in the three species. Other useful characters for distinguishing the species are epidermal cell size, stomata size and stomata number.

Keywords: Digitaria iburua, microhairs, foliar, silica bodies, Digitaria exilis
\end{abstract}

\section{INTRODUCTION}

The grass family, Poaceae, is noted for its wide diversity and complexity and so has posed many problems to the taxonomists using the traditional method based on gross morphology (Srivastava, 1978). The family is one of the largest and is economically the most important of all plants that cover the earth; being classified into about 50 tribes, 908 genera and more than 11,000 species (GPWG, 2001; Lowe, 1989). In West Africa, there are approximately 147 genera and 615 species (Gill, 1988).

The genus Digitaria Haller comprises annual and perennial grass species and is almost confined to the tropical and warm temperate regions of the world, frequently forming an important part of the savannah grasses in the tropics. According to Hutchinson and Dalziel (1972), there are 26 species of Digitaria in West Africa, $18 \mathrm{spp}$. of which also occur in Nigeria. Digitaria exilis Stapf (white fonio) is a staple food in various parts of West Africa and probably the oldest African cereal. It is the most culturally diverse and widely cultivated species in West Africa, locally called Acha, Ipouaga, Feningué, Findi, Kansambahon and Ova in Nigeria, Benin, Burkina Faso, Guinea, Mali and Togo respectively (Adoukonou-Sagbadja, 2010). Digitaria iburua Stapf (black fonio) is cultivated as a cereal in scattered localities from Côte d'Ivoire to northern Nigeria and southern Niger, and in Cameroon. It has also been reported to be grown in Guinea and DR Congo. Black fonio is only known from cultivation. Its origin is uncertain, but it may have been derived from Digitaria ternata (A.Rich.) Stapf (Portères, 1976). Digitaria barbinodis Hanr. is recorded only in Mali and Northern Nigeria (Burkill, 1994).

The black and white fonio require minimal processing due to grain size and location of constituents. The starch of Digitaria exilis can be employed as an alternative binder to maize starch binding property in the formulation of paracetamol tablets (Musa et al., 2008). Due to it low free sugar and low glycemic content, Digitaria species is recommended for lactating women, diabetic people and often used in diets of sick people (Kwon-Ndung et al., 2003). The straw of $D$. exilis can be chopped and mixed with clay for building houses, walls burnt and the ash extracted with water to make potash and a source of heat for cooking (Hag and Ogbe, 1995). Black fonio is a staple food of the Birom people of the Jos Plateau in Northern Nigeria and an important supplementary food to people in the Atakora mountains of Togo and Benin. It is eaten as porridge or mixed with meal of other cereals. The grain is also eaten cooked like rice or in stews. In Benin and Nigeria black fonio is made into couscous types (wusu-wusu). In Togo it is used for brewing beer ('tchapalo') (Irvine, 1974).

Digitaria iburua Stapf, Digitaria exilis Stapf and Digitaria barbinodis Hanr. are very similar morphologically, often confused (Hutchinson and Dalziel, 1972). Their identification depends principally on their seed morphology which has seasonal occurrence. This often takes some time to develop, therefore studies have to wait for a considerable length of time for the plant to mature and the organ to be available. The leaf epidermis is described as an important character after cytology for solving this taxonomic problem (Stace, 1984; Strivastava, 1978).

Metcalfe (1960) studied abaxial epidermal anatomy of Digitaria borbonica Desv., D. brazzae (Franch.) Stapf, D. horizontalis Willd., D. nzilanjiana (Rendle) Stapf and D. wallichiana (Wight \& Am.) Stapf. Webster (1983) revised the genus Digitaria of Australia. 
He studied morphological as well anatomical characters of 38 species of Digitaria. While studying the leaf epidermal anatomy of the genus, he examined the abaxial leaf surface only. Several studies have also been conducted on other genera and tribes belonging to the family Poaceae using leaf epidermal and anatomical features to aid their identification and classification (Sharma and Salam, 1984; Sharma and Mittal, 1985; Gill and Mensah, 2001; Kharazian, 2007; Folorunso and Olaniyan, 2009).

The present investigation aimed to explore the possible use of microscopic characters of the leaf to identify samples of these very similar but economically important and culturally diverse grass species. The study will be useful in the determination of the patterns of variation in epidermal characteristics, assessing their value in species identification and classification, and also in establishing the taxonomic relationships among the species studied.

\section{MATERIALS AND METHODS}

The study was carried out in the Botany Laboratory, Department of Plant Science \& Technology, University of Jos. Fresh leaf samples of three Digitaria species (Digitaria exilis, Digitaria barbinodis and Digitaria iburua) were collected from the botanical garden, University of Jos $\left(9.933^{\circ} \mathrm{N} 8.883^{\circ} \mathrm{E}\right)$ and Riyom Local Government Area of Plateau state $\left(9.567^{\circ} \mathrm{N} 8.667^{\circ} \mathrm{E}\right)$.

Preparation of leaf samples for permanent slides to enhance epidermal morphology follows the method of Wilkinson (1979), with slight modifications. The leaf samples were soaked in concentrated nitric acid for three to five hours in order to remove the colouring pigments and surface debris followed by washing in several changes of water to remove excess reagents. Using the fine grade carmel hair brush, epidermal peels were carefully removed from the leaf sample surfaces and cleared properly. The cleared epidermal peels were stained in aqueous solution of Safranin 0 for 4-8 minutes, rinsed carefully in water to remove excess stain and mounted in Canada balsam.

The slides of both abaxial and adaxial surfaces of the leaves were prepared, labelled, viewed for micromorphological characters with the digital Olympus BX 51 light microscope and photomicrographs were captured on the computer. Where measurements were taken, in the cases of stomata length and width and the epidermal cells, the range corresponds to two major levels of discontinuity (smallest and highest values). Specimens were observed at X400 objective magnification.

The stomata index was determined according to Metcalfe and Chalk (1979) using the formula: $\frac{\mathrm{S}}{\mathrm{E}+\mathrm{S}} \times \frac{100}{1}$ stomata index (S.I)

Where $S=$ Number of stomata per unit area and $E=$ number of epidermal cells in the same area

\section{RESULTS}

The results obtained from the study of the surface features of Digitaria species are shown in Plates 1a-3b as photomicrographs and tabulated in Tables 1 and 2 . Figure 1 is the dendrogram of possible phyletic relationships among the three species. Anatomical description of the foliar epidermal characters with specific references to stomata complex, epidermal cell complex, silica bodies, short cells and micro hairs, for each species, are described below.

\section{Digitaria iburua Stapf}

The distribution of stomata was epiamphistomatic (stomata abundant on the adaxial surface and scanty on the abaxial epidermis). Large numerous paracytic stomata type with dome shaped subsidiary cells were observed on both surfaces (Plate 1a). The stomata size on the abaxial surface measured $30-37.4 \mu \mathrm{m}$ long and $20.4-23.8 \mu \mathrm{m}$ wide while stomata size measuring $34.0-37.4 \mu \mathrm{m}$ long and $20.4 \mu \mathrm{m}$ wide was found on the adaxial surface (Table2). The stomata index on the abaxial and adaxial surfaces was $19.34 \%$ and $29.3 \%$ respectively.

The epidermal cell shape was rectangular on both surfaces while the anticlinal wall pattern was highly wavy in the abaxial surface but slightly wavy in the adaxial surface. The epidermal size on the abaxial measured 53.0-158.6 $\mu \mathrm{m}$ long and 20.4-34.0 $\mu \mathrm{m}$ wide while epidermal size measuring 68.0-142.8 $\mu \mathrm{m}$ long and $20.4-27.2 \mu \mathrm{m}$ wide was found on the adaxial surface (Table 2). Micro hairs were absent on both surfaces. Numerous short cells and dumb-bell shaped silica bodies were seen in the intercoastal zones on both surfaces.

\section{Digitaria exilis Stapf}

The stomata distribution was hypoamphistomatic (stomata abundant on the adaxial surface and scanty on the abaxial epidermis). Large numerous paracytic stomata type with dome shaped subsidiary cells present (Plate 2a). The stomata size on the abaxial

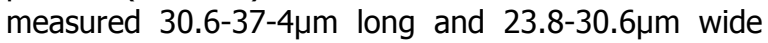
while stomata size measuring $30.6-40.8 \mu \mathrm{m}$ long and 23.8-30.6 $\mu \mathrm{m}$ wide was found on the adaxial surface (Table 2). The stomata index on the abaxial and adaxial surfaces was $24.2 \%$ and $17.8 \%$ respectively. The epidermal cell shape on both surfaces was long and polygonal and the anticlinal wall pattern was straight. The epidermal size on the abaxial surface measured 74.8-136.0 $\mu \mathrm{m}$ long and 20.4-34.0 $\mu \mathrm{m}$ wide while epidermal size measuring $74.8-129.2 \mu \mathrm{m}$ long and $34.0-44.2 \mu \mathrm{m}$ wide was seen on the adaxial surface (Table 2). Micro hairs and dumb-bell shaped silica bodies were present on both surfaces while short cells were absent.

\section{Digitaria barbinodis Henrard}

Stomata distribution was epiamphistomatic. Paracytic stomata type, numerous on the adaxial than on the abaxial surface was observed. The stomata type observed on both surfaces was paracytic with triangular dome shaped subsidiary cells (Plate 3a). The stomata size on the abaxial measured 27.2$34.0 \mu \mathrm{m}$ long and $23.8 \mu \mathrm{m}$ wide while stomata size measuring 23.8-30.6 $\mu \mathrm{m}$ long and $20.4-23.8 \mu \mathrm{m}$ wide was found on the adaxial surface (Table2). The stomata index on the abaxial and adaxial surfaces was $4.36 \%$ and $8.5 \%$ respectively. On both surfaces, the epidermal cell shape was rectangular while the anticlinal wall pattern was straight. The epidermal size on the abaxial measured $23.8-30.6 \mu \mathrm{m}$ long and 20.4$23.8 \mu \mathrm{m}$ wide while epidermal size measuring 54.4$129.2 \mu \mathrm{m}$ long and $34.0-37.4 \mu \mathrm{m}$ wide was seen on the adaxial surface (Table2). 
Short cells were present on the adaxial surface but absent on the abaxial surface while dumb bell silica bodies were present on the intercoastal zones on both surfaces. Micro hairs were also observed on both surfaces.

TABLE 1: QUALITATIVE EPIDERMAL CHARACTERS EXTRACTED FROM THE MICROGRAPHS OF THE STUDIED SPECIES

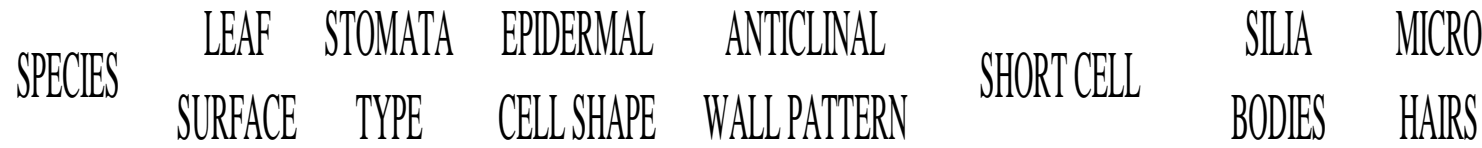

\begin{tabular}{|c|c|c|c|c|c|c|c|}
\hline & & & & & +1. & +1. & +1. \\
\hline \multirow[t]{2}{*}{ D. iburula } & $A B$ & Paracytic & Long rectangular & Highly wavy & t & $t$ & \\
\hline & $A D$ & Paracytic & Long rectangular & Slightly wavy & $t$ & $t$ & . \\
\hline \multirow[t]{2}{*}{ D.exilis } & $A B$ & Paracytic & Polygonal & Straight & - & $t$ & $t$ \\
\hline & $A D$ & Paracytic & Polygonal & Straight & - & $t$ & t \\
\hline \multirow[t]{2}{*}{ D.barbinodis } & $A B$ & Paracytic & Shoot rectangular & Straight & - & t & + \\
\hline & $A D$ & Paracytic & Shott rectangullar & Straight & t & t & + \\
\hline
\end{tabular}

TABLE 2: QUANTITATIVE EPIDERMAL CHARACTERS EXTRACTED FROM THE MICROGRAPHS OF THE STUDIED SPECIES

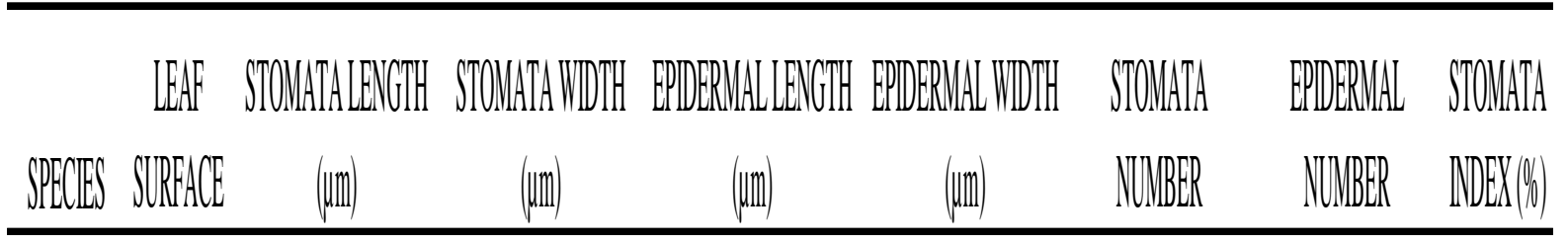

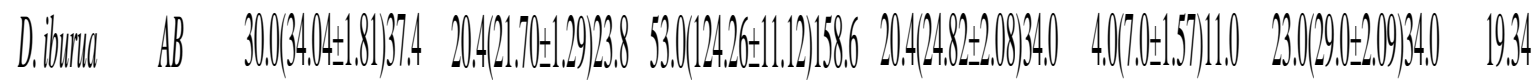

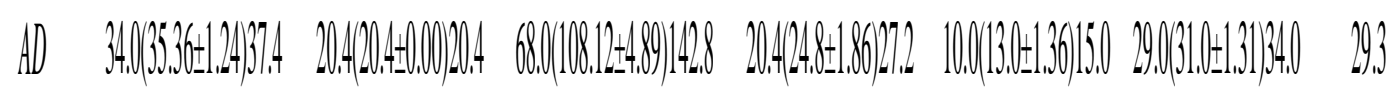

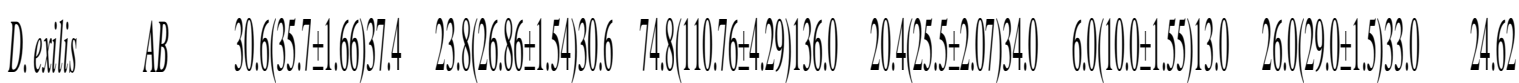

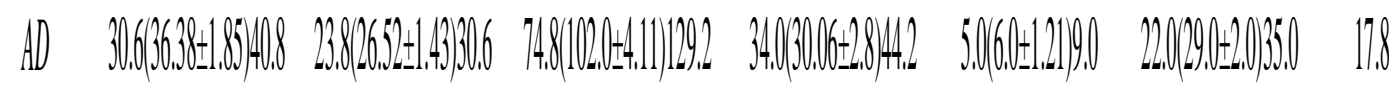

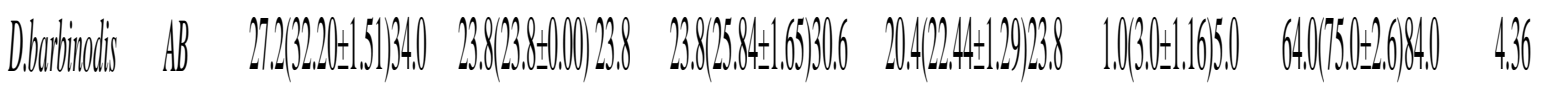

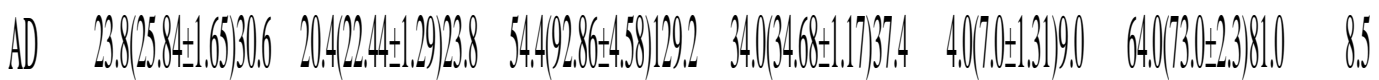

Key: Min. (mean \pm standard error) max.

AB: Abaxial

AD: Adaxial 


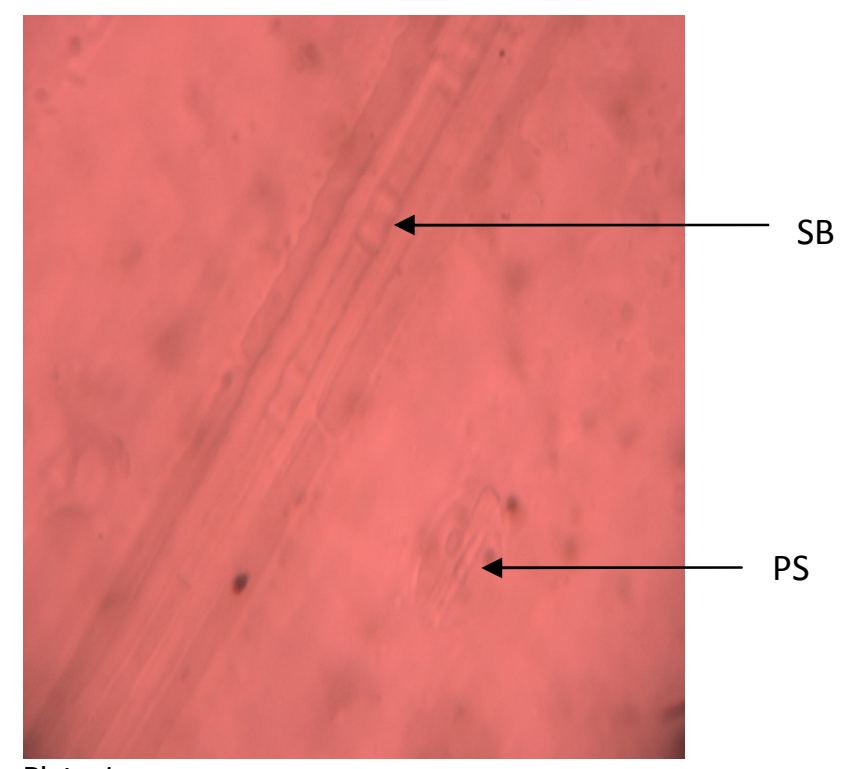

Plate 1a

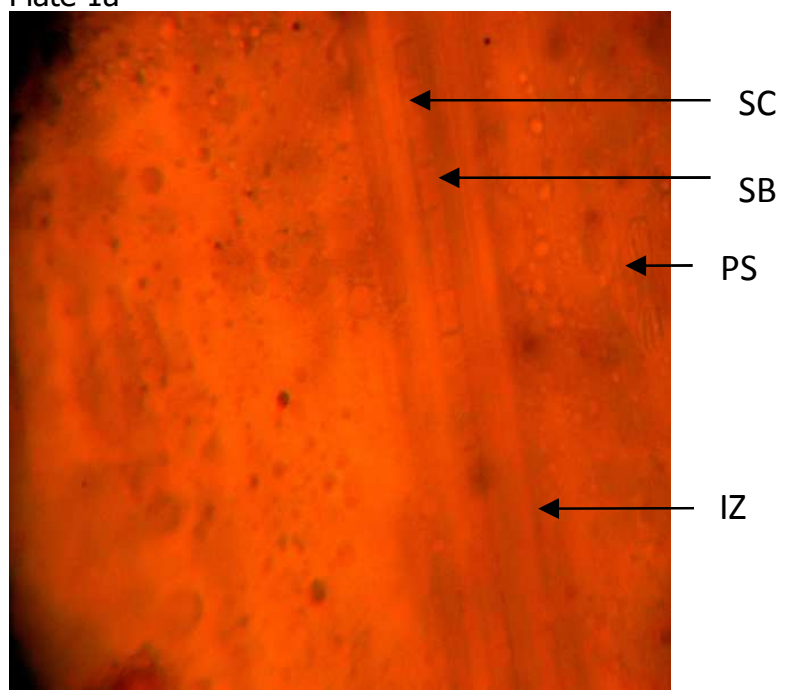

Plate $1 b$

Plates 1a and 1b: Abaxial and adaxial surfaces of $D$. iburua

Abbreviations: Paracytic stoma (PS), silica body (SB) and intercoastal Zone (IZ), short cell (SC)

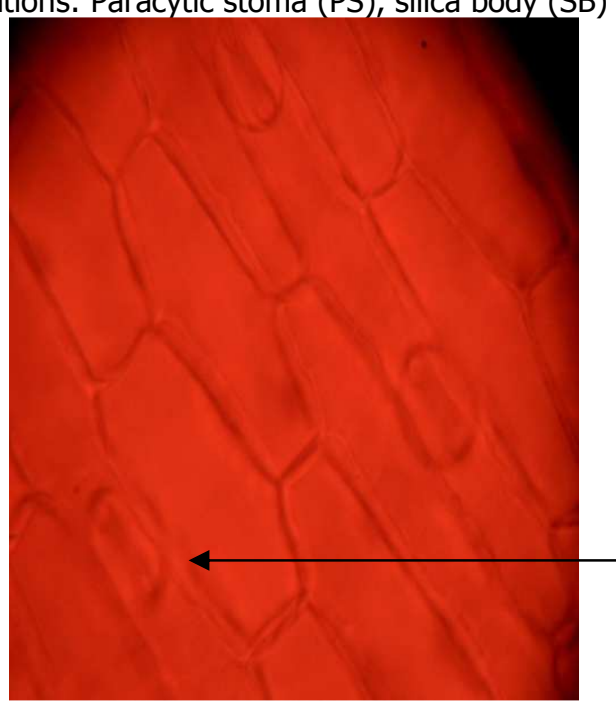

Plate $2 a$ 
Bajopas Volume 7 Number 2 December, 2014

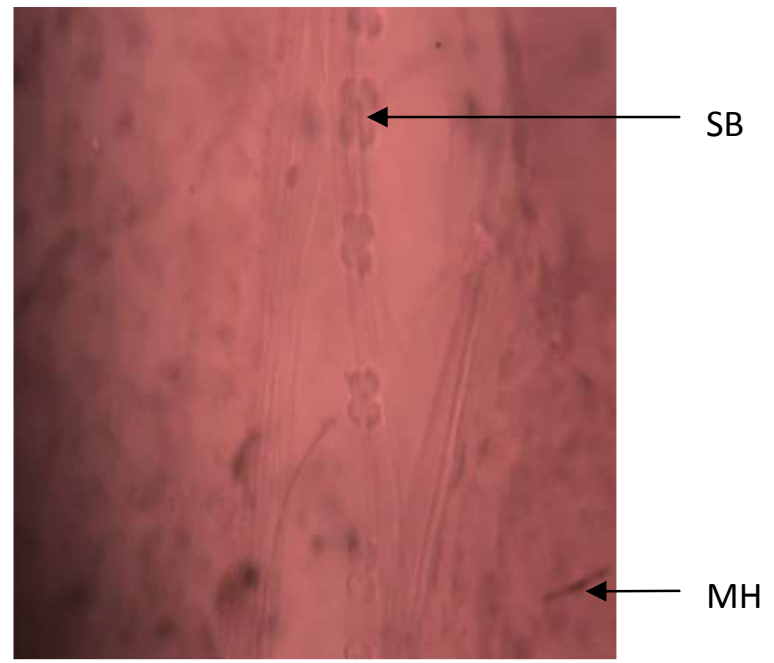

Plate $2 b$

Plates 2a and 2b: Adaxial and abaxial surfaces $D$. exilis

Abbreviations: Paracytic Stoma (PS), micro hairs (MH), silica bodies (SB)

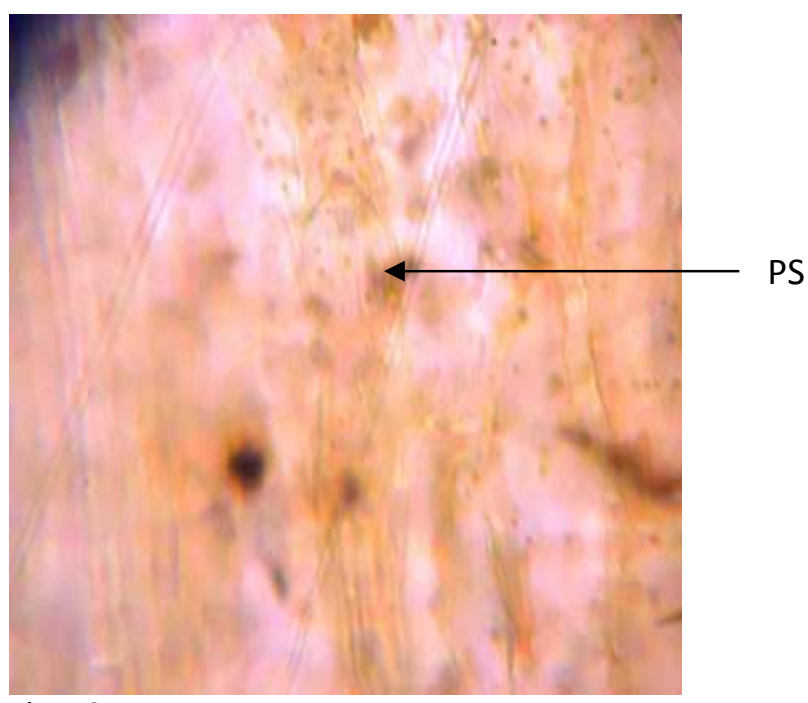

Plate $3 a$

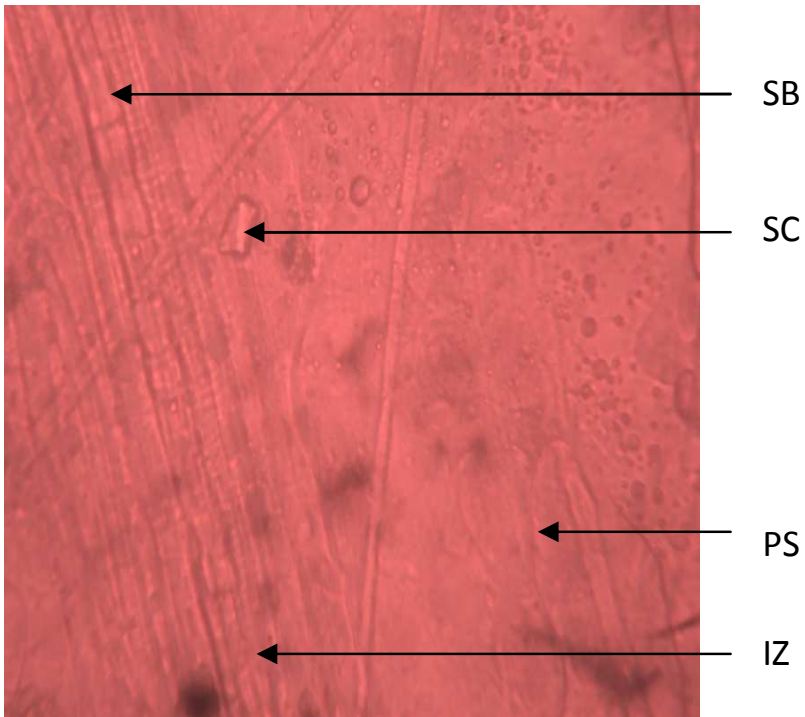

Plate $3 b$

Plates 3a and 3b: Abaxial and adaxial surfaces of $D$. barbinodis

Abbreviations: Paracytic stoma (PS), intercoastal Zone (IZ), silica bodies (SB) 


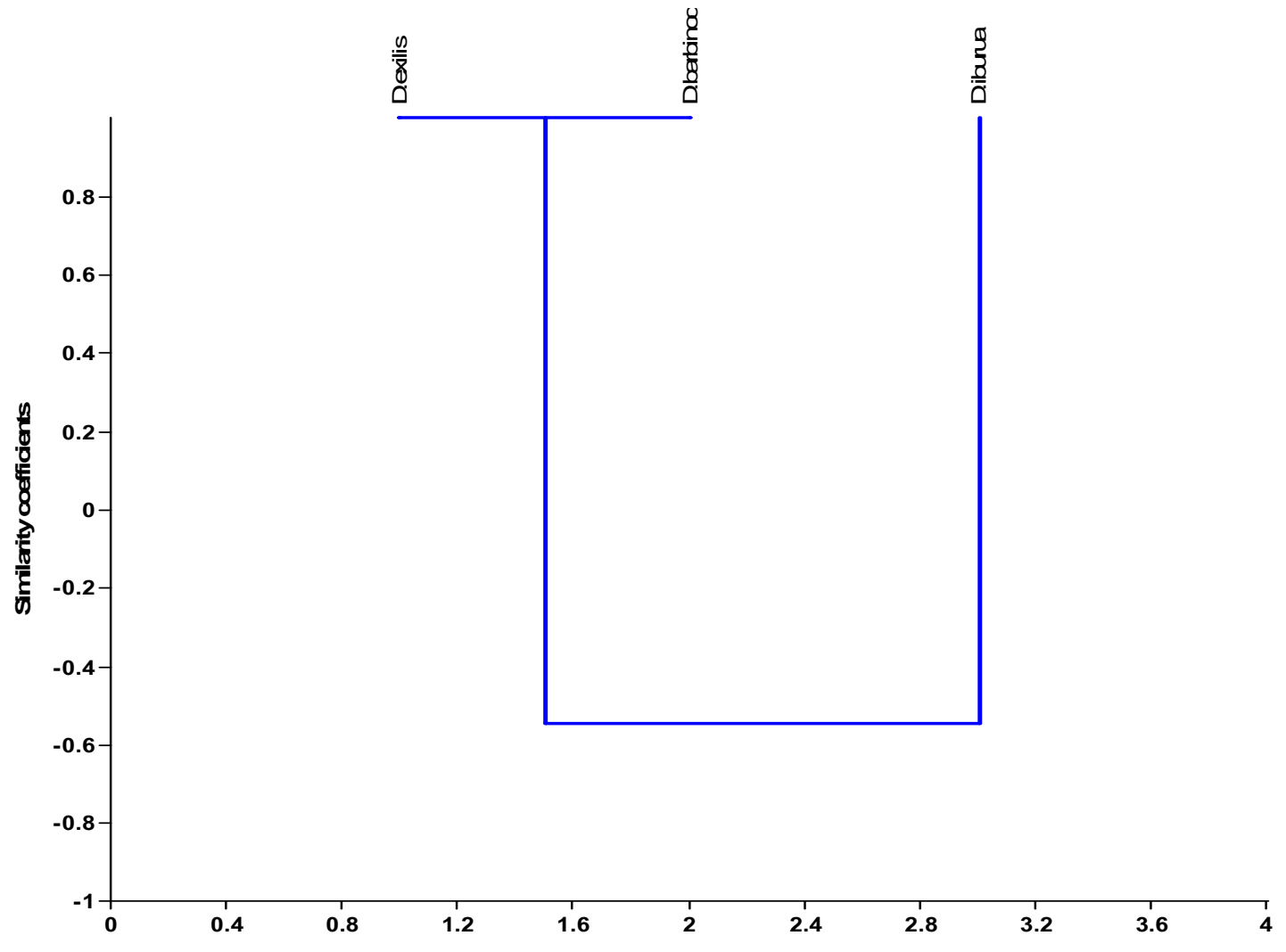

Fig. 1: Dendrogram of relationships among the Digitaria species studied based on epidermal foliar characters.

A study of the dendrogram in Figure 1 reveals that D.exilis and D. barbinoidis are very similar, almost inseparable while $D$. iburua appears distant from both.

\section{DISCUSSION}

Broadly, the leaf epidermal attributes of the three species are quite similar regarding the length and width of the stomata, while the stomata index is quite different. In this study, the stomata index is helpful in species delimitation; thus separating the species into two groups. Digitaria iburua and Digitaria exilis with stomata index greater than $10 \%$ and Digitaria barbinodis having stomata index less than $10 \%$. Paracytic stomata type was observed which had dome shaped or triangular subsidiary cells. Triangular subsidiary cells were observed in Digitaria barbinodis while dome shaped subsidiary cells were observed in $D$. iburua and $D$. exilis. This is in agreement with the study of Syed et al. (2002) which reported the presence of paracytic stomata type with dome shaped, parallel or triangular subsidiary cells in the Digitaria species studied. Metcalfe and Chalk (1954) pointed out that certain characters of the epidermis of Poaceae such as shape of the subsidiary cells of the stomata, micro hairs, short cells and silica bodies are important systematically. Metcalfe and Chalk (1979) and Aworinde et al. (2009) reported that stomata complex is highly constant for a given species and can be used in species identification.

Furthermore, the shape of the epidermal cells and the anticlinal wall pattern vary between the species studied and can be used as distinguishing tools with Digitaria iburua possessing rectangular epidermal cell shape and wavy anticlinal wall pattern, Digitaria exilis having long polygonal cell shape and straight anticlinal walls pattern while rectangular cell shape and straight anticlinal wall pattern were observed in Digitaria barbinodis. This is partly in agreement with the study of Farooq (2009) which reported polygonal cell shape and sinuous anticlinal wall pattern in the Digitaria species studied.

The closeness observed in the dendrogram between Digitaria exilis and Digitaria barbinodis is in consonance with previous studies. The presence of micro hairs on the surfaces of Digitaria exilis and Digitaria barbinodis distinguished them from Digitaria iburua that lack micro hairs, in agreement with the findings of Farooq (2009) which reported the presence of micro hairs in some Digitaria species. Ogei-odia et al. (2010) stressed the importance of micro hairs as diagnostic character. In this study, the presence or absence of micro hairs can be useful in distinguishing the species. Other characteristic features of the leaf epidermis were short cells which were present on both the adaxial and abaxial surfaces of Digitaria iburua, but only observed on the adaxial surface of Digitaria barbinodis while absent on the surfaces of Digitaria exilis, thereby providing a diagnostic tool to distinguish between these species. This is partly in agreement with the findings of Syed et al. (2002), which reported the presence of short cells in the three Digitaria species studied. 
The presence of dumb bell-shaped silica bodies observed between the intercoastal zones on the three species studied appears to be synapomorphic for the species which thus supports the reported similarities (Hutchinson and Dalziel, 1972). This is in agreement with Farooq (2009) and Freire et al. (2005) who also observed presence of dumb bell-shaped silica bodies in the species studied.

\section{CONCLUSION}

Leaf epidermal studies have proved to be very important in providing information of taxonomic importance. Diagnostic characters for distinguishing the species include presence or absence of micro hairs, epidermal cell shape, anticlinal wall pattern, stomata index and presence or absence of silica bodies. Thus, micromorphological characters

\section{REFERENCES}

Adoukonou-Sagbadja H. (2010). Genetic Characterization of Traditional Fonio millets (Digitaria exilis, D. iburua Stapf) Landraces from West-Africa: Implications for Conservation and Breeding. Thesis. Institute of Crop Science and Plant Breeding I. JustusLiebig University Giessen, Germany; 119.

Aworinde, D.O., D.U. Nwoje, A.A Jayeola, A.A. Olagoke and A.A. Ogundele (2009). Taxonomic Significance of foliar Epidermis in some members of Euphorbiaceae family in Nigeria. Research Journal of Botany. 4:17-28

Burkill, H.M. (1994). The useful plants of West Tropical Africa. Vol. 2. $2^{\text {nd }}$ edition. Families E-I. Kew: Royal Botanic Gardens; 636

Farooq, A. (2009). Taxonomic studies of grasses of salt range of pakistan. Ph.D Thesis Quaid-iAzam University Islambad Pakistan.

Folorunso, A.E. and O.F. Olaniyan (2009). Comparative foliar epidermal studies in Andropogon gayanus (Kunth) and Andropogon tectorum (Schum and Thonns) in Nigeria. Thaiszia Journal of Botany 19: 27-35

Freire, S.E., A. M. Arambarri, N.D. Bayon, G. Sancho, E. Urtubey, C. Monti, M.C. Novoa and M.N. Cotares (2005). Epidermal characteristics of toxic plants for cattle from the Salado Rivers Basin. Bol. Soc. Argent. Bot. 40:3-4

Gill, L.S. (1988). Taxonomy of flowering plants. Onitsha, Nigeria: Africana - Feb Publishers Limited.

Gill, L.S. and Mensah, J.K. (2001). Epidermal and leaf anatomical studies of the tribe Eragrostideae (Poaceae) from West Africa. Journal of Plant Anatomy and Morphology 25: 41-58.

GPWG (Grass Phylogeny Working Group) (2001). Phylogeny and subfamilial classification of the garsses (Poaceae). Ann. Missouri Bot. Garden 88: $373-457$.

Hag, N and D. Ogbe (1995). Fonia (Digitaria exilis and Digitaria iburua). Cereal and Peusdo cereals. (Under-utilized crops) William, J.T (ed.) Longman Chapman and Hall; 225 - 224 presented in the current study sustain the difference between the three species on the basis of a key given below:

Silica bodies present on both surfaces in the three species
1. micro hairs
present.
2
2 short cells only on abaxial surface Digitaria barbinodis
2 short cells on both adaxial and abaxial
surfaces
1. micro hairs Digitaria exilis

absent.......

ria iburua

Hutchinson J. and J.M. Dalziel (1972). Floral of West Tropical Africa Vol.III Part 2. London: Crown Agents; 459-461

Irvine, F.R. (1974). West African Crops. London : Oxford University Press; 148-149

Kharazian, N. (2007). The Taxonomy and variation of leaf anatomical characters in the Genus Aegilops L. (Poaceae) in Iran. Turkish Journal of Botany 1: 1-9.

Kwon-Ndung, E., H. Dachi, M. Ukwungu and E.D. Imolehin (2003). Potential role of biotechnology tools for genetic improvement of 'lost crops of Africa'; the case of fonio (Digitaria exilis and Digitaria iburua). African Journal of Biotechnology 2(12): 580-585.

Metcalfe, C .R. and L. Chalk (1954). Recent work on the systematic anatomy of the monocotyledon (with special reference to investigation of the Jodrell lab at Kew). Kew Bull 9(4): 523-532.

Metcalfe, C.R. and L. Chalk (1979). Anatomy of Dicotyledons. Vol.1.2 ${ }^{\text {nd }}$ ed. Oxford : The Clarendon Press; 1-275.

Metcalfe, C.R. (1960). Anatomy of monocotyledons. I. Gamineae. Oxford: The Clarendon Press.

Musa, H.A., J. Muazu, and P.G. Bhatia (2008). Nigerian Journal of Pharmaceutical Sciences 7: $34-38$

Ogie-Odia , E.A., D. Eseigbe, M.N. Ilechie, J. Erhabor and E. Ogbebor (2010). Foliar epidermal and phytochemical studies of the grasses Cymbopogon citratus (Stapf.), Axonopus compressus (P. Beauv.) and Eragrostis tremula (S. W. Beauv) in Ekpoma, Edo State, Nigeria. Science World Journa/ 5:1-3

Portères, R. (1976). African cereals: Eleusine, fonio, black fonio, teff, Brachiaria, paspalum, Pennisetum, and African rice. Origins of African Plant Domestication. Harlan J.R., de Wet, Stemler J.M.J. (eds) The Hague: Mouton Publishers; 409-452.

Sharma, M.L. and H.R. Mittal (1985). Leaf epidermal studies in Gramineae V. Genus Eragrostic P. Beauv. Research Bulletin of the Pangab University 37: 29-35. 
Sharma, M.L. and A. Salam (1984). Biosystematic survey of the Dactyloctenium aegyptium complex (Gramineae) in Punjab plains II. Leaf epidermis. Research Bulletin of the Pangab University 5: 7- 11.

Stace, C.A. (1984). The taxonomic importance of the leaf surface. Current concepts in plant Taxonomy Systemic Association Special, vol. 25, Academic Press, London.

Strivastava, A.K. (1978). Study of leaf epidermis in the genus Digitaria Rich (Gramineae). Journal of Indian Botanical Society 37:155-160
Syed, S.G., K. AJAB, K.S. Zabta and Y. Zubaida (2002). Leaf epidermal anatomy of selected Digitaria species, tribe Paniceae, family Poaceae of Pakistan. Pakistan Journal of Botany 34(3): 257-273.

Webster, R. D. (1983). A revision of the genus Digitaria Haller (Paniceae, Poaceae) in Australia. Brunonia 6: 131-216.

Wilkinson, H.P. (1979). The Plant Surface (mainly leaf). Anatomy of Dicotyledons. Metcalfe C.R., Chalk L. (eds) (Vol. 1. 2nd edn). Oxford: The Clarendon Press; 40-53. 